\title{
ALUMINUM IN CORN PLANTS: INFLUENCE ON GROWTH AND MORPHO-ANATOMY OF ROOT AND LEAF ${ }^{(1)}$
}

\author{
Michelli Fernandes Batista ${ }^{(2)}$, Ismar Sebastião Moscheta ${ }^{(3)}$, Carlos Moacir Bonato ${ }^{(4)}$, \\ Marcelo Augusto Batista ${ }^{(5)}$, Odair José Garcia de Almeida ${ }^{(6)}$ \& Tadeu Takeyoshi Inoue ${ }^{(7)}$
}

\begin{abstract}
SUMMARY
Aluminum (Al) toxicity is one of the most limiting factors for productivity. This research was carried out to assess the influence of $\mathrm{Al}$ nutrient solution on plant height, dry weight and morphoanatomical alterations in corn (Zea mays L.) roots and leaves. The experiment was conducted in a greenhouse with five treatments consisting of $\mathrm{Al}$ doses $\left(0,25,75,150\right.$, and $\left.300 \mu \mathrm{mol} \mathrm{L}^{-1}\right)$ and six replications. The solutions were constantly aerated, and the $\mathrm{pH}$ was initially adjusted to 4.3 . The shoot dry matter, root dry matter and plant height decreased significantly with increasing Al concentrations. Compared to the control plants, it was observed that the root growth of corn plants in Al solutions was inhibited, there were fewer lateral roots and the development of the root system reduced. The leaf anatomy of plants grown in solutions containing 75 and $300 \mu \mathrm{mol} \mathrm{L} \mathrm{L}^{-1} \mathrm{Al}$ differed in few aspects from the control plants. The leaf sheaths of the plants exposed to $\mathrm{Al}$ had a uniseriate epidermis coated with a thin cuticle layer, and the cells of both the epidermis and the cortex were less developed. In the vascular bundle, the metaxylem and protoxylem had no secondary walls, and the diameter of both was much smaller than of the control plants.
\end{abstract}

Index terms: dry matter production, height, toxicity, Zea mays L.

(1) Part of Dissertation of Master degree from first author presented for Graduate Program of Agronomy (PGA), State University of Maringá (UEM). Received for publication on April 26, 2012 and approved on November 9, 2012.

(2) Biologist, Ph.D. student, Biology Department, UEM. Av. Colombo, 5790, Bloco G-80. CEP 87020-900 Maringá (PR). E-mail: mfernandes_2@hotmail.com

(3) Biologist, Associate Professor, Biology Department, UEM. E-mail: ismoscheta@uem.br

(4) Agronomist, Associate Professor, Biology Department, UEM. E-mail: cmbonato@uem.br

(5) Agronomist, Adjunct Professor, Agronomy Department, UEM. Av. Colombo, 5790, Bloco J-45. CEP 87020-900 Maringá (PR). E-mail: mabatista@uem.br

(6) Biologist, Ph.D. student, Botany Department, Universidade Estadual Paulista (UNESP). Rio Claro (SP). E-mail: odair1000@hotmail.com

(7) Agronomist, Adjunct Professor, Agronomy Department, UEM. E-mail: ttinoue@uem.br 


\title{
RESUMO: ALUMÍNIO EM PLANTAS DE MILHO: INFLUÊNCIA NO CRESCIMENTO E NA MORFOANATOMIA DA RAIZ E DA FOLHA
}

\begin{abstract}
A toxicidade do aluminio (Al) é um dos fatores mais limitantes para a produtividade. Esta pesquisa foi realizada para avaliar a influência do Al, em solução nutritiva, na altura de plantas, no peso da matéria seca e nas alterações morfoanatômicas de raízes e folhas de milho (Zea mays L.). O experimento foi conduzido em casa de vegetação com tratamentos constituídos de cinco doses de $\mathrm{Al}\left(0 ; 25 ; 75 ; 150 ;\right.$ e $\left.300 \mu \mathrm{mol} \mathrm{L} \mathrm{L}^{-1}\right)$ e seis repetições. As soluções foram constantemente aeradas e o $\mathrm{pH}$ foi ajustado a 4,3, inicialmente. A matéria seca da parte aérea e das raízes e a altura das plantas diminuíram significativamente com o aumento da concentração de Al. As raízes de plantas de milho cultivadas em soluções com Al tiveram seu crescimento inibido e apresentaram menos raizes laterais e desenvolvimento do sistema radicular inferior, em comparação com as das plantas-controle. As folhas das plantas crescidas em soluções que continham 75 e $300 \mu \mathrm{mol} \mathrm{L}{ }^{-1}$ de Al não apresentaram muita diferença anatômica em relação às das plantas-controle. A bainha da folha das plantas exposta ao Al apresentou epiderme uniestratificada revestida por uma fina camada de cutícula e as células da epiderme e do córtex foram as que menos se desenvolveram. No feixe vascular, o metaxilema e protoxilema não tinham paredes secundárias, e o diâmetro de ambos foi muito menor quando comparado com os das plantas-controle.
\end{abstract}

Termos para indexação: produção de massa seca, altura, toxicidade, Zea mays $L$.

\section{INTRODUCTION}

Corn (Zea mays L.) is a cereal, and cereals are the most consumed agricultural products in the world. (FAO, 2010). In general, corn is a sensitive crop to aluminum (Al), and the number of studies on the effects of aluminum on the growth of annual agricultural crops has increased. The toxicity caused by $\mathrm{Al}$ is one of the most yield-limiting factors because $\mathrm{Al}$ is the most abundant metal in the earth crust (Kochian et al., 2004), occurring in $30 \%$ of the icefree areas and in $40 \%$ of the agricultural lands in the world. In Brazil, acid soils are predominantly located in the tropical and subtropical regions (von Uexckull \& Mutert, 1995).

The toxicity caused by $\mathrm{Al}$ interferes with enzymatic reactions, the metabolism of several elements and with plasmatic membrane permeability (Kochian, 1995). Moreover, $\mathrm{Al}$ inhibits root elongation and the induction of callose synthesis, which appears after a short exposure time to $\mathrm{Al}$ (Horst et al., 1997). Usually, the Al toxicity effect is noticed in the roots before any symptom becomes evident in the aerial regions (Pintro et al., 1995; 1996; Veloso et al., 2000; Kochian, 2000), which can be confirmed by $\mathrm{Al}$ accumulation in the root distal region, indicating the area of highest sensitivity. Therefore, the root apex is the primary site of toxic action of $\mathrm{Al}$ (Matsumoto \& Motoda, 2012).

Changes in the volume of the root cap were observed by Bennet \& Breen (1991) in Al- treated corn plants. Bennet et al. (1987) observed that a significant alteration in the mean cell volume is limited to the cap periphery where $\mathrm{Al}$ causes a decrease in cell volume. Cha \& Lee (1996) studied the effects of different $\mathrm{Al}$ levels on the growth and root anatomy of Alnus hirsute Rupr, and reported that A1-treated root tissues have the following microscopic characteristics compared to untreated root tissues: presence of electron-dense bodies in the vacuoles and between the plasmalemma and cell wall; accumulation of phenolic materials in vacuoles; disrupted tonoplast; and increased vacuolation. There are only few studies on the changes in plant morphoanatomy caused by $\mathrm{Al}$ toxicity. Importantly, these changes are more intense in roots than in shoots because the roots are in direct contact with aluminum.

Thus, the objective of this study was to evaluate the influence of $\mathrm{Al}$ on the height and dry matter production (shoot and root) of corn plants. In addition, the structural alterations were also studied through the morphoanatomical analyses of the roots and leaves of corn plants grown in nutrient solutions containing different $\mathrm{Al}$ concentrations.

\section{MATERIAL AND METHODS}

\section{Growth study}

The experiment lasted 21 days during which corn plants (triple hybrid AS-3466) were grown in a nutrient solution under controlled conditions at the Universidade Estadual de Maringá, Paraná State, Brazil, in May 2004.

The phytotoxic effect of aluminum on corn was evaluated at five $\mathrm{Al}$ levels $(0,25,75,150$, and 300 $\mu \mathrm{mol} \mathrm{L}{ }^{-1}$ ) with six replications, with 30 experimental units each. The experiment was arranged in a completely randomized block design.

For germination, the corn seeds were placed in paper rolls moistened with water, which were then 
stored in covered plastic containers at room temperature. After germination, eight plants were selected according to the development of the roots and aerial parts.

The experimental units consisted of plastic pots with two plants each. The pots were filled with $10 \mathrm{~L}$ of ionized water $\left(\mathrm{CE}=6 \mathrm{mS} \mathrm{cm}^{-1}\right)$ with $400 \mathrm{mmol} \mathrm{L}^{-1}$ $\mathrm{CaCl}_{2} 2 \mathrm{H}_{2} \mathrm{O}$. The initial $\mathrm{pH}$ of the solution was adjusted to 4.3 for three days before the beginning of the experiment in order to stabilize the $\mathrm{pH}$ of the solution. The $\mathrm{pH}$ was not adjusted during the plant development until after 21 days.

The corn plants were grown in medium density fiber (MDF) boards using Styrofoam. Each MDF board had six perforations as follows: four lateral perforations for fixing the plants; a central hole to place the aeration system of the solution; and one perforation in the intermediate part of the board, which was used for monitoring the nutrient solution $(\mathrm{pH}$ and $\mathrm{CE}$ readings). To avoid the growth of algae in the cultivation solution, the plastic pots were covered with black plastic bags to block light.

The nutrient sources consisted of three nutrient stock solutions, according to Blair \& Taylor (2004), which contained: $0.1750 \mathrm{~mol} \mathrm{~L}^{-1} \mathrm{NH}_{4} \mathrm{NO}_{3}$, $0.077 \mathrm{~mol} \mathrm{~L}^{-1} \mathrm{NH}_{4} \mathrm{Cl}, 0.0015 \mathrm{~mol} \mathrm{~L}^{-1} \mathrm{Mg}\left(\mathrm{NO}_{3}\right)_{2} 6 \mathrm{H}_{2} \mathrm{O}$, $0.0385 \mathrm{molL}^{-1} \mathrm{MgCl}_{2} 6 \mathrm{H}_{2} \mathrm{O}, 0.05 \mathrm{~mol} \mathrm{~L}^{-1} \mathrm{Ca}\left(\mathrm{NO}_{3}\right)_{2}$ $4 \mathrm{H}_{2} \mathrm{O}, 0.0420 \mathrm{~mol} \mathrm{~L}^{-1} \mathrm{HNO}_{3}, 0.047 \mathrm{~mol} \mathrm{~L}^{-1} \mathrm{KH}_{2} \mathrm{PO}_{4}$, $0.128 \mathrm{~mol} \mathrm{~L}^{-1} \mathrm{KNO}_{3}, \quad 0.02 \mathrm{~mol} \mathrm{~L}^{-1} \quad \mathrm{~K}_{2} \mathrm{SO}_{4}$, $0.00073 \mathrm{~mol} \mathrm{~L}^{-1} \mathrm{MnSO}_{4} \mathrm{H}_{2} \mathrm{O}, 0.0018 \mathrm{~mol} \mathrm{~L}^{-1} \mathrm{H}_{3} \mathrm{BO}_{3}$, $0.00009 \mathrm{~mol} \mathrm{~L}^{-1} \mathrm{ZnSO}_{4} 7 \mathrm{H}_{2} \mathrm{O}$, and $0.0000007 \mathrm{~mol} \mathrm{~L}^{-1}$ $\left(\mathrm{NH}_{4}\right)_{6} \mathrm{Mo}_{7} \mathrm{O}_{24} 4 \mathrm{H}_{2} \mathrm{O}$.

In the end of the experimental period, the plants were collected, photographed and separated into shoot and root portions. The material was labeled and airdried to constant weight at $65{ }^{\circ} \mathrm{C}$ in an oven with forced-air circulation. After drying, the shoot and root parts were weighed. The values of the shoot and root dry matter production and height (only of the aerial part) were tabulated for further statistical analysis.

\section{Morpho-anatomical study}

For the anatomic study, corn plants were grown at the following $\mathrm{Al}$ concentrations: 1) control, i.e., nutrient solution without $\mathrm{Al}$; 2) nutrient solution with $75 \mu \mathrm{mol} \mathrm{L}-1 \mathrm{Al}$; and 3) nutrient solution with $300 \mu \mathrm{mol}$ $\mathrm{L}^{-1} \mathrm{Al}$.

The plants were fixed in formalin-acetic alcohol. (FAA) (Johansen, 1940) and preserved in $70 \%$ ethanol (Jensen, 1962). For the slides, roots and leaves of corn plants were collected. For this study, the chosen parts of the plant were the mid- region of the leaf and the main root. Using a rotation microtome, cross sections of leaf and root, and longitudinal root sections were cut (Sass, 1951). To obtain permanent slides, the material was placed in HistoResin, according to the technique described by Guerrits (1991). The obtained sections were stained with toluidine blue (O'Brien et al., 1964) and prepared in Permount, and the results were illustrated through photomicrographs taken with a Zeiss microcamera.

\section{Statistical analyses}

The independent variables, including shoot dry matter production, root dry matter production and height, were adjusted by a linear regression method, known as the routine PROC REG, using SAS/STAT software (SAS, 2000).

\section{RESULTS AND DISCUSSION}

\section{Dry mass production of shoot and root}

The shoot and root dry matter production decreased with increasing $\mathrm{Al}$ concentration in the nutrient solution (Figure 1a). According to Farias et al. (2011), increasing $\mathrm{Al}$ levels in the nutrient solution led to a decline in the shoot and root dry matter production, as demonstrated in our results.

Independent of the Al levels, the dry matter production of shoots was higher than of roots, at all tested $\mathrm{Al}$ levels. The proportional decrease of the shoot dry matter production was higher than that of the root dry matter production. For each unit variation in $\mathrm{Al}$ level, decreases of 0.00341 and $0.00145 \mathrm{~g}$ were observed in the shoot and root dry matter production, respectively.

The shoots of the corn plants were damaged more than the roots by the harmful effects of $\mathrm{Al}$, which may have occurred because the plants were kept in the same nutrient solution during the entire experimental period. Many studies (Pintro et al. 1995, 1996; Kochian et al., 2004) showed that roots are more affected than shoots. In these experiments, however, the nutrient solutions were renewed every day to assure that the mineral concentration, especially $\mathrm{Al}$ concentration, as well as the ionic strength and $\mathrm{Al}$ activity all remained constant.

The low dry matter accumulation in the shoot may be attributed to the significant effect of $\mathrm{Al}$ on nutrient absorption and translocation (Azevedo \& Oliva, 1989). The soluble $\mathrm{Al}$ in soil makes the plant uptake of several elements difficult, and one of these elements is P (Batista et al., 2009). The low translocated content of $\mathrm{P}$ to the plant shoots reduces the photosynthetic rate, which causes a lower accumulation of carbohydrates, thereby resulting in lighter leaves with less dry matter production (Rheinheimer et al., 1994).

All of these effects can affect the biomass production of corn plants. Thereby, higher Al levels in the nutrient solution result in higher inhibition of the dry matter production (Figure 1a). 

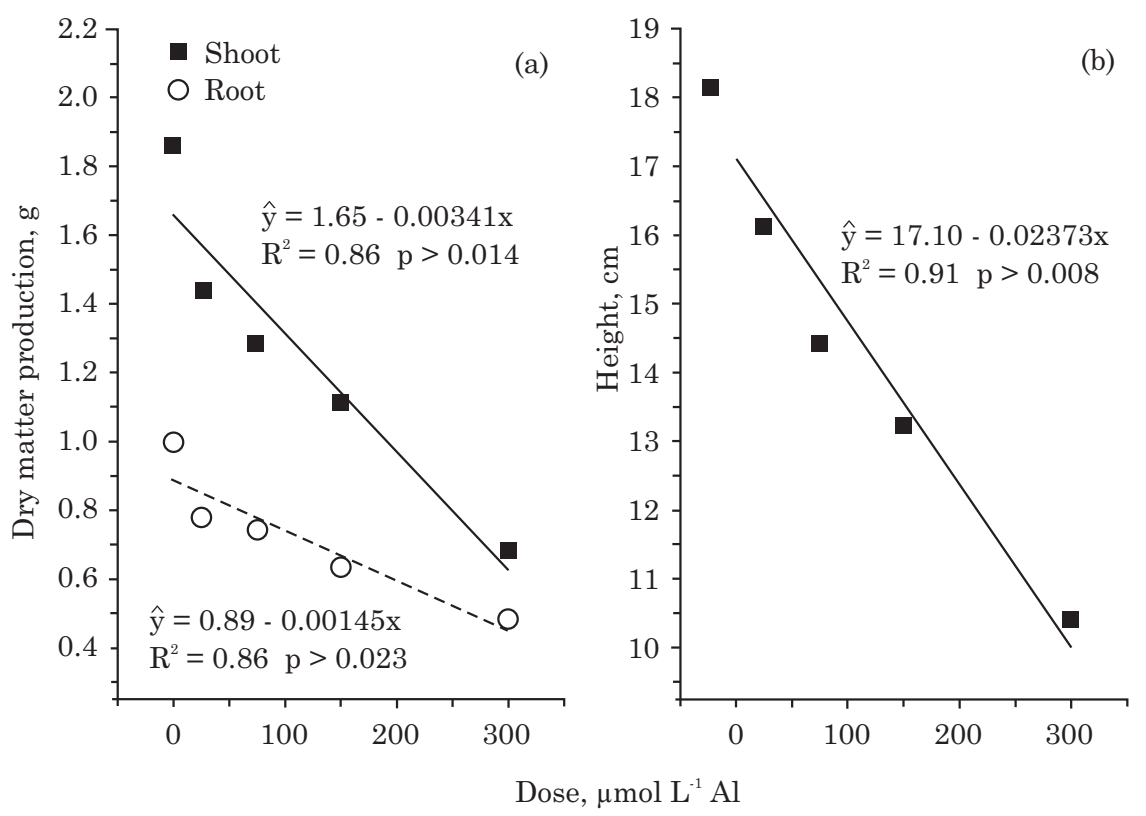

Figure 1. a) Shoot and root dry matter production and b) height of corn plants exposed to different Al concentrations during the experimental period of 21 days.

\section{Height of corn plants}

The plant height decreased with increasing $\mathrm{Al}$ contents in the nutrient solution (Figure 1b). These results were similar to those of Beutler et al. (2001), who studied the forest species Moringa oleifera Lam and Anadenanthera peregrine L., which were found to be sensitive to low $\mathrm{Al}$ contents in the nutrient solution $\left(0.0,2.5,5.0,7.5\right.$ and $\left.10.0 \mathrm{mg} \mathrm{L}^{-1}\right)$, resulting in a linear reduction of the plant height.

Thus, the plant height, which is one of the most limiting factors for productivity, was reduced by $\mathrm{Al}$ toxicity; the initial effect of $\mathrm{Al}$ on growth retardation adversely influenced later development. The primary effect of $\mathrm{Al}$ toxicity is manifested by the fast root growth inhibition, which results from a complex interaction between $\mathrm{Al}$ and the root apex (Ryan et al., 1993). The response is quick (less than $1 \mathrm{~h}$ ) because the first process inhibited by $\mathrm{Al}$ in the roots is cell elongation and not cell division (Matsumoto, 2000). However, with the increased exposure time to $\mathrm{Al}$, the root growth inhibition (Figure 1a) includes both processes as follows: blockade of cell division and inhibition of cell elongation (Kochian, 1995). The molecular and biochemical bases of Al toxicity are not well-known, although it is likely that a large number of processes associated with the root apoplast and symplast are influenced by $\mathrm{Al}$.

\section{Morpho-anatomy of root and leaf of corn plants without Al-addition}

The corn plants grown in nutrient solution without $\mathrm{Al}$ developed as expected for the species (Figure 2a). The roots of these plants are thin, whitish and long with a large number of lateral roots, which indicated an extensive and efficient root system, typical of monocotyledons.

The epidermal tissue is uniseriate with isodiametric and overlapping cells (Figure 2b,c). A thin cuticle covers the epidermis. The cortical parenchyma is located on the internal side of the epidermis (Figure $2 \mathrm{~b}, \mathrm{c})$ and consists of several layers of isodiametric cells with prominent intercellular spaces, which are essential for the aeration of root cells. As the plants were grown in nutrient solution, these spaces were highly developed forming the auriferous parenchyma. The specialty of this parenchyma is air storage, and its appearance is common in aquatic plants (Scatena \& Scremin-Dias, 2003), as a form of adaptation. The endodermis is formed by compactly arranged cells without intercellular spaces and with " $U$ " thickening (Figure 2e).

The central cylinder is present in the center of the root (Figure 2b,c) and consists of vascular tissues, the pericycle and the pith. The pericycle is composed of a single layer of parenchyma cells with thin overlapping cell walls with different shapes and sizes, and the cells are larger than those of the endodermis. The protoxylem occupies the outer position of the vascular cylinder (next to the pericycle) with cells that are tracheal and narrower, and these cells are the first to maturate. The metaxylem occupies the closest position to the center of the central cylinder, and it is composed of larger caliber tracheal cells, which begin to perform the function of the metaxylem later. The phloem strands alternate with the xylem peripheral parts, and they occupy the external position of the central cylinder next to the pericycle. Thus, the arrangement of the vascular tissues is called radial 
or alternating because the conductor tissues are interchangeably placed. The root structure was classified as polyarch (Figure 2b). At the center of the vascular cylinder, there is the pith, which is welldefined and composed only of parenchyma cells (Figure $2 \mathrm{c}, \mathrm{d}, \mathrm{e})$.

The corn plant has invaginating leaves with several overlapping sheaths in the young stage, which was when the observations were made in this study. The sheath is composed of a uniseriate epidermis coated with a thin cuticle layer (Figure 3a). The parenchyma tissue is located internally to the epidermis, and consists of cells of several sizes (Figure $3 \mathrm{~b}$ ). The vascular bundles are collaterals, that is, the phloem is more external than the xylem; and in the xylem, the protoxylem is the innermost part (Figure $3 b$ ). The vascular bundles are surrounded by the vascular bundle sheath or endodermis and by the pericycle (Figure $3 b$ ). This bundle sheath was considered an endodermoid cover by Esau (1959) and an endodermis

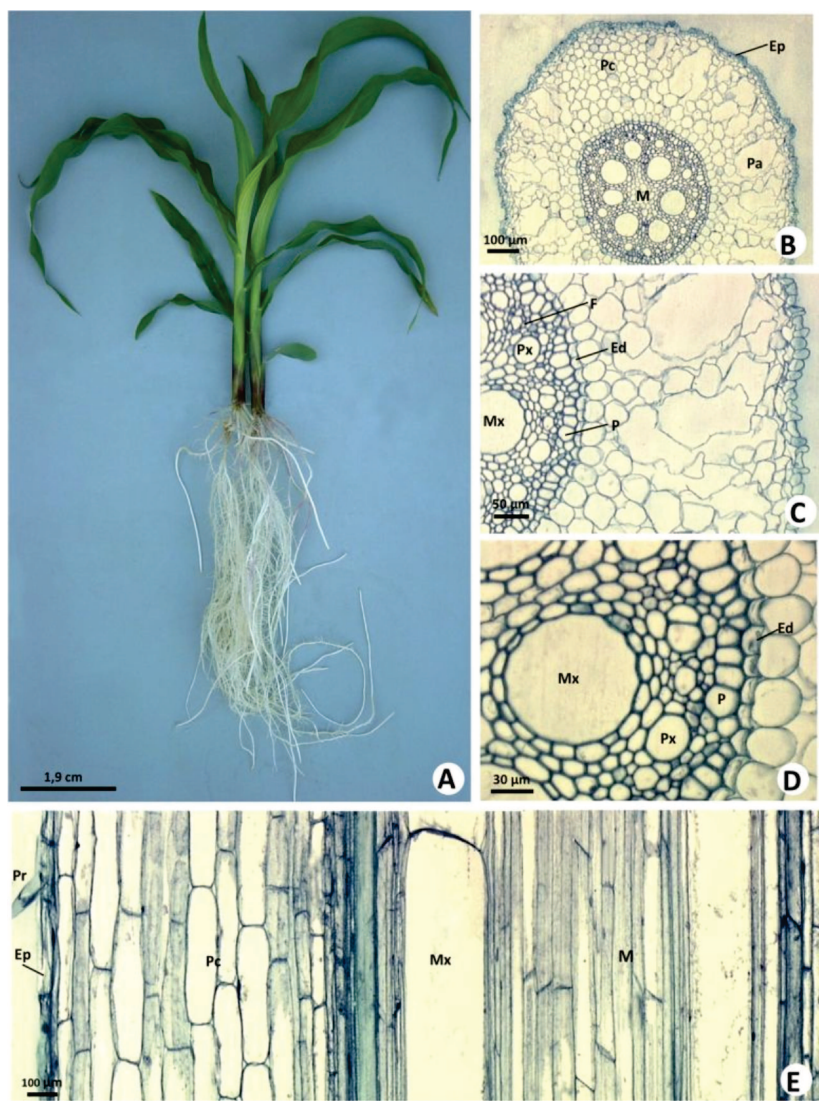

Figure 2. a) Corn plant grown in nutrient solution without $\mathrm{Al}$ addition. $\mathrm{b}, \mathrm{c}, \mathrm{d})$ Transversal sections of a corn root. $d$ ) Endodermis detail with " $U$ " thickening. e) Longitudinal section of a corn root with root hair. Ed, endodermis; Ep, epidermis; F, phloem; M, pith; Mx, metaxylem; $\mathbf{P}$, pericycle; Pa, aeriferous parenchyma; Pc, cortical parenchyma; $\mathbf{P r}$, root hair; and $\mathbf{P x}$, protoxylem. containing Casparian strips in the corn leaf bundles by Menezes et al. (2003).

The limbo of the control plant (Figure 3c,d), despite being similar to the sheath structure, is thinner and has more chloroplast in the parenchyma cells. The limbo has a uniseriate epidermis that is hairless with overlapping cells of several sizes both on the abaxial and adaxial face, and the adaxial face is slightly smaller than the abaxial face. The epidermal cells are covered with a thin cuticle. The leaf is amphistomatic because the stomata occur on both the abaxial and adaxial face, and the substomatal chambers are present on the internal side of the stomata (Figure 3c).

The mesophyll is homogeneous and is composed of rounded and polygonal cells with intercellular spaces that are not clearly visible (Figure 3c). According to Menezes et al. (2003), the endodermis or vascular bundle sheath cells in monocotyledons are arranged in a radiated way forming a crown, called "Kranz anatomy".

In the midrib, the vascular bundles are distributed near the adaxial face, and a larger central vascular bundle has a string of lignified fibers with bundle sheath extensions (Figure 3c). Brito et al. (1997) reported that the sheath extension provides support to the leaf as the cells of this extension consist of fibers. In the smaller vascular bundles, which are the secondary and tertiary veins, it was not possible to

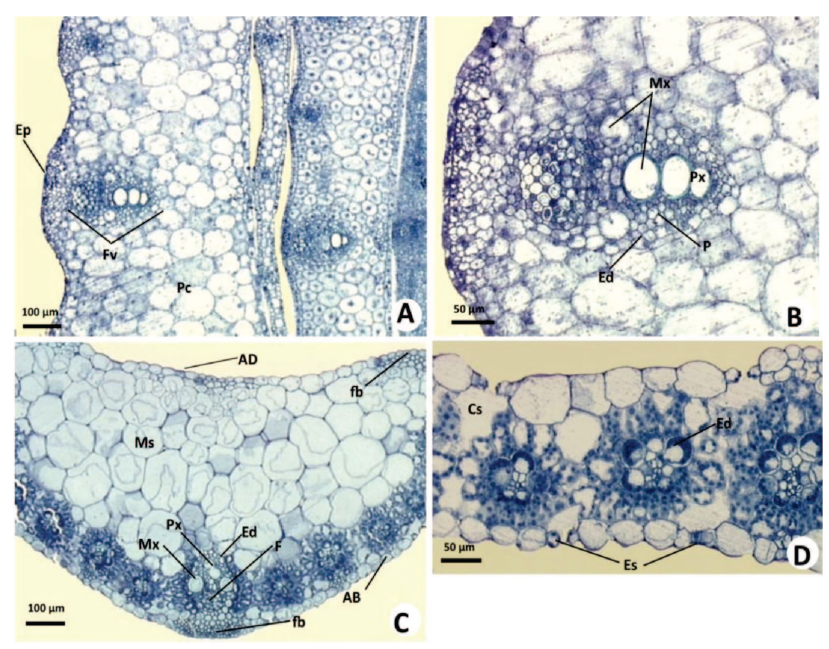

Figure 3. Longitudinal section of a corn leaf grown in nutrient solution without addition of aluminum. a) Sheaths of the stem median region. b) Detail of the external sheath vascular bundle. c) Median region of the limbo with the midrib. d) Detail of the vascular bundles and stomata. $\mathrm{AB}$, abaxial face epidermis; $\mathrm{AD}$, adaxial face epidermis; Cs, substomatal chamber; Ed, endodermis; Ep, epidermis; Es, stomata; F, phloem; fb, fiber; Fv, vascular bundle; Ms, mesophyll; Mx, metaxylem; $P$, pericycle; Pc, cortical parenchyma; and $\mathbf{P x}$, protoxylem. 
distinguish phloem and xylem, because the xylem tacheary elements had not been differentiated at this point.

\section{Morphology and anatomy of corn plants exposed to Al}

The root growth of the corn plants grown in the nutrient solution with $75 \mu \mathrm{mol} \mathrm{L}-1 \mathrm{Al}$ was inhibited and the number of lateral roots was reduced, presenting a less developed root system compared to the control plant (Figure 4a). Lima \& Copeland (1994) also used $75 \mu \mathrm{mol} \mathrm{L} \mathrm{L}^{-1} \mathrm{Al}$, and reported that $\mathrm{Al}$ does not affect the aerial part of wheat but that it affects the root system by causing the primary roots to become dark and brittle with brown apices in addition to inhibiting the secondary roots. According to Göransson \& Eldhuset (1991), the following typical root morphology injuries are caused by $\mathrm{Al}$ : root darkening, formation of short roots and inhibition of lateral root development. Thus, most studies have shown that the inhibition of root growth is the most

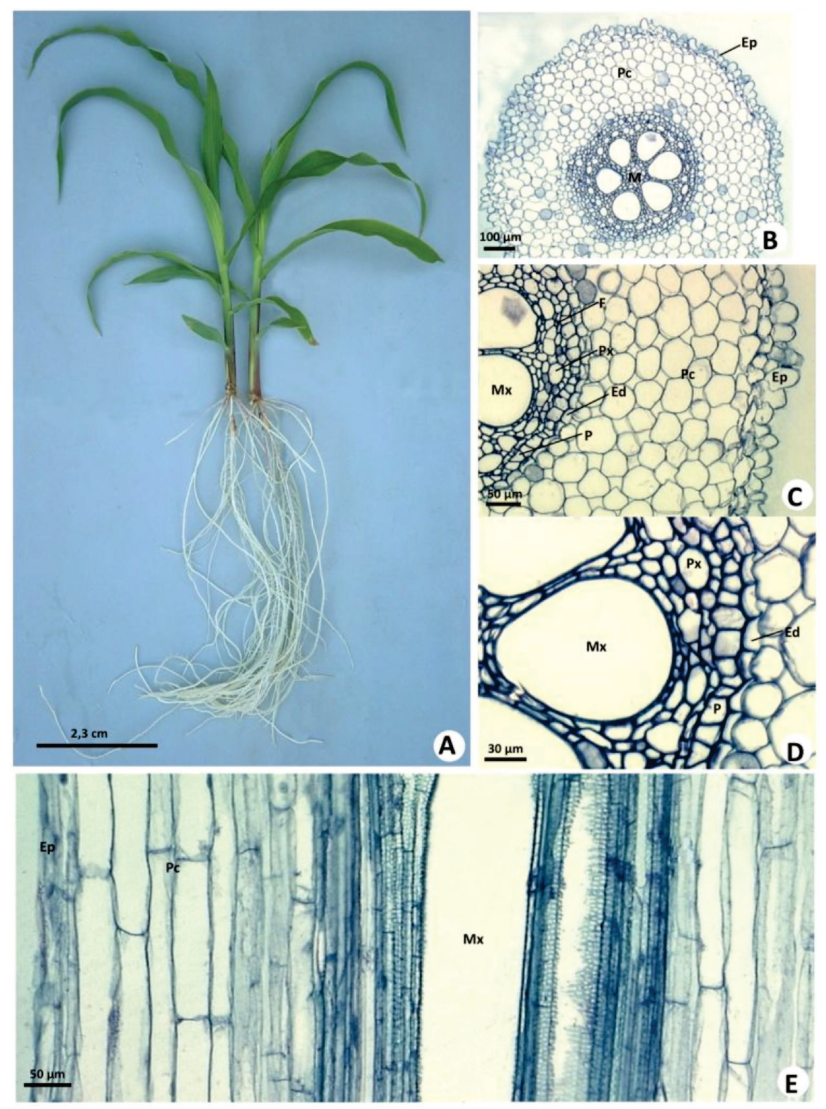

Figure 4. a) Corn plant grown in nutrient solution containing $75 \mu \mathrm{mol} \mathrm{L}^{-1} \mathrm{Al}$. b, c and d) Transversal section of the root. d) Detail of the endodermis with " $U$ " thickening. e) Longitudinal section of the root. Ed, endodermis; Ep, epidermis; F, phloem; M, pith; $M x$, metaxylem; $P$, pericycle; Pc, cortical parenchyma; and Px, protoxylem. visible and immediate result of $\mathrm{Al}$ toxicity in plants, and many authors suggest that the primary cause of this symptom is the reduction of mitosis in the root apical meristem cells (Echart \& Cavalli-Molina, 2001).

At $75 \mu \mathrm{mol} \mathrm{L}^{-1} \mathrm{Al}$, the effect of $\mathrm{Al}$ did not clearly discriminate the lining, filling and conduction tissues of the root (Figure 4b,c). The epidermis consists of overlapping cells with highly variable shape and size. The cortex presents a higher amount of intercellular space, and its cells were elongated longitudinally (Figure 4c,e). The endodermis showed visible ribs in the "U" (Figure 4c,d). The metaxylem had a larger diameter of oval-shaped cells in relation to the control plant, and it developed secondary walls. The secondary walls owe their strength and stiffness to lignin, which provides the structural reinforcement of plants required for the vertical growth above the soil. The caliber vessels of the protoxylem, which is different from the metaxylem, were smaller (Figure 4c). The presence of a pith was clearly visible, but its space was reduced, which may have been a consequence of the larger diameter of the metaxylem (Figure $4 \mathrm{~b}$ ).

The increase in cell expansion depends on the apparent hydraulic conduction, cell wall extensibility, turgidity pressure, and water potential difference among the cells and their surroundings. Thus, the negative influence of $\mathrm{Al}$ on any of these patterns changes the growth rate and cell expansion (Barceló et al., 1996). Thereby, the increase in cell volume can be explained by the fact that Al-stressed roots have a decreased pressure potential of root cells, which reduces the apparent hydraulic conductivity, thereby indicating that aluminum severely affects the ratio of root water (Echart \& Cavalli-Molina, 2001).

The plants exposed to $300 \mu \mathrm{mol} \mathrm{L}{ }^{-1} \mathrm{Al}$ in the growth solution showed a poorly developed root system. The number of roots was greatly reduced with little formation of lateral roots and a shorter length compared to the plants grown in 0 and $75 \mu \mathrm{mol} \mathrm{L}{ }^{-1} \mathrm{Al}$ (Figure 5a). Clark (1997) and Pavan \& Binghan (1982) reported frequent nutritional disorders with reduced levels of $\mathrm{Ca}, \mathrm{Mg}, \mathrm{K}$, and $\mathrm{P}$ in the tissues of plants grown in Al-containing substrates. These deficiencies occur because $\mathrm{Al}$ induces callose deposition in the plasmodesmata channels, physically inhibiting the symplastic transport between cells (Sivaguru et al., 2000). According to Kinraide \& Parker (1987), one of the major phytotoxic effects on plants is root growth reduction caused by the inhibition of the cell division process, which directly affects nutrient absorption, assimilation and transport, thereby resulting in more mineral nutrients, such as $\mathrm{Ca}$ and $\mathrm{Mg}$.

Despite the high $\mathrm{Al}$ dosage $(300 \mu \mathrm{mol} \mathrm{L}-1)$, the root tissues were still distinguishable (Figure $5 \mathrm{~b}$ ). The epidermis appeared to be necrotic. The cortical parenchyma consisted of larger (turgid) but fewer cells with large intercellular spaces and cell walls with an 
undulating appearance. A larger auriferous parenchyma appeared in this region, and no "U" thickening was observed in the endodermis (Figure 5c). According to Ikeda \& Tadano (1993), Al induces drastic changes in the morphology of some cortical cells of barley roots. It is also believed that Al-poisoned cells contain a dense material between the cell wall and the plasmatic membrane (Ciamporová, 2000).

In the central cylinder, it was difficult to identify the phloem and pericycle due to the "fragility" of the plant material resulting from cultivation at a high $\mathrm{Al}$ concentration $\left(300 \mu \mathrm{mol} \mathrm{L} \mathrm{L}^{-1}\right)$. As the control plant, the root also had a polyarch structure, with seven xylem strands (Figure 5a). The metaxylem was not covered by a secondary wall, which is characteristic of a still immature tissue. Moreover, the format was not the same in all xylem vessels, as some were larger and others thinner, and the format in the xylem vessels was not similar to the format in the metaxylem vessels. The protoxylem and metaxylem vessels also had a deformed appearance without a developed

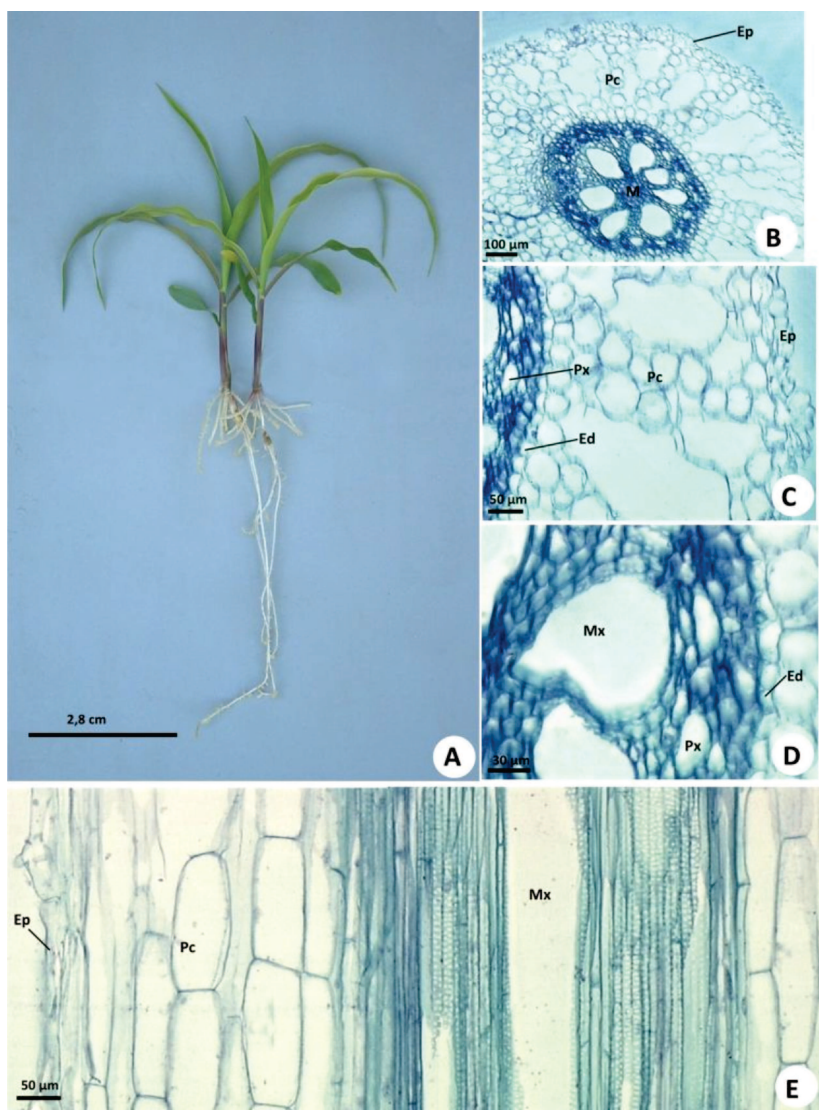

Figure 5. a) Corn plant grown in nutrient solution containing $300 \mu \mathrm{mol} \mathrm{L-1}$ Al. b, c, d) Transversal sections of the root. d) Details of the endodermis with " $U$ " thickening. e) Longitudinal sections of the root. Ed, endodermis; Ep, epidermis; F, phloem; M, pith; Mx, metaxylem; P, pericycle; Pc, cortical parenchyma; and $\mathbf{P x}$, protoxylem. secondary wall, and were small compared to the control plant (Figure 5c,d). The region of the pith parenchyma was poorly developed (Figure $5 \mathrm{~b}$ ).

The most affected part of the root by $\mathrm{Al}$ toxicity was the central cylinder region (Figure 5b), where the cells were darker and difficult to identify. These results disagreed with those of Ouzounidou et al. (1995), who reported that cells in the epidermal tissue of corn are most affected by the action of $\mathrm{Al}$ and observed no structural disorder of the hypodermis. A similar result was reported by Budíková et al. (1997), who used $50 \mu \mathrm{mol} \mathrm{L}-1 \mathrm{Al}$ and showed that the epidermis and peripheral cortex layers are more affected than the central cylinder cells. Although the literature indicates that $\mathrm{Al}$ affects the epidermal, cortical and subepidermal tissues, this study demonstrated that $300 \mu \mathrm{mol} \mathrm{L}{ }^{-1} \mathrm{Al}$ causes structural impairment, including impairment of the central cylinder.

Apoplasma injuries caused by $\mathrm{Al}$ can lead to simplasma injuries by passing through the cell wall, plasmatic membrane and cytoskeleton (Sivaguru et al., 1999; Horst et al., 1999). Primarily and predominantly, $\mathrm{Al}$ accumulates in the apoplast of the root where pectin with its negative charge is the binding site (Blamey et al., 1990). The bonds of $\mathrm{Al}$ with pectin and other cell wall constituents can change its characteristics and functions, such as extensibility, porosity and enzymatic activities, mainly by inhibiting root growth (Schmohl \& Horst, 2000). These facts might justify the change in the cell wall shape of root cells resulting from the addition of $300 \mu \mathrm{mol} \mathrm{L}^{-1} \mathrm{Al}$ to the nutrient solution.

The entrance of $\mathrm{Al}$ in the plasmatic membrane through the interaction with the lipid components causes stiffening of the membrane (Deleers et al., 1986), which affects its metabolism. Several plant responses to $\mathrm{Al}$ have been reported as a result of the alterations in the plasmatic membrane functions (Jones \& Kochian, 1997), including calcium channel blockade, electrical potential transmembrane depolarization (Papernik \& Kochian, 1997), and organic acid exudation (malate, aspartate and oxalate) when the cultivar is Al-tolerant (Delhaize \& Ryan, 1995), as well as the induction of callose production due to the increase of intracellular $\mathrm{Ca}^{2+}$, which can be caused by the influx of $\mathrm{Ca}^{2+}$ through the damaged plasmatic membrane (Delmer \& Amor, 1995).

In the treatments with 75 and $300 \mu \mathrm{mol} \mathrm{L}^{-1} \mathrm{Al}$, the roots were harmed. Al caused growth inhibition and a concomitant increase in the root diameter, indicating that the cytoskeleton may be the phytotoxic cellular target of Al (Blancaflor et al., 1998). The cytoskeleton is a dynamic system of protein elements located mainly in the cytosol and also in the nucleus of all plant cells, especially acting in cell growth and differentiation (Kraus et al., 2003). In addition to these functions, the cytoskeleton is also involved in other processes, such as cell division, cell expansion, cell wall synthesis and organelle movement through the 
cytoplasm (Seagull, 1989). Thus, inhibition of some of these functions will affect the normal development of the plant.

The poor root development caused by $\mathrm{Al}$ was due to the following processes: its interference in the cell division process; an increase in cell wall rigidity caused by an increased number of crossed bonds among pectin molecules in the same cell wall; reduction in the process of DNA replication by the increased rigidity of its double helix; fixation of $\mathrm{P}$ in less available forms in soil and surfaces close to the roots; and decrease in the root respiratory rate and consequent decrease in the absorption processes, transport and use of essential elements, such as Ca, $\mathrm{Mg}, \mathrm{K}, \mathrm{P}$, and Fe (Foy, 1983).

The morphological symptoms of Al phytotoxicity in the aerial plant parts were not easily identifiable. In some species, the symptoms are similar to phosphorus deficiency. In other species, however, the set of symptoms induced by $\mathrm{Al}$ toxicity are confused with those of Ca deficiency, with the possibility of the occurrence of typical internerval chlorosis of iron deficiency (Taylor et al., 1998).

In the leaves of Al-treated plants few anatomical differences were observed in relation to the control plant. The leaf sheath of the plants grown in solution containing $75 \mu \mathrm{mol} \mathrm{L}-1 \mathrm{Al}$ presented a uniseriate epidermis and three layers of internal cells of the uniseriate epidermis with thickened secondary walls

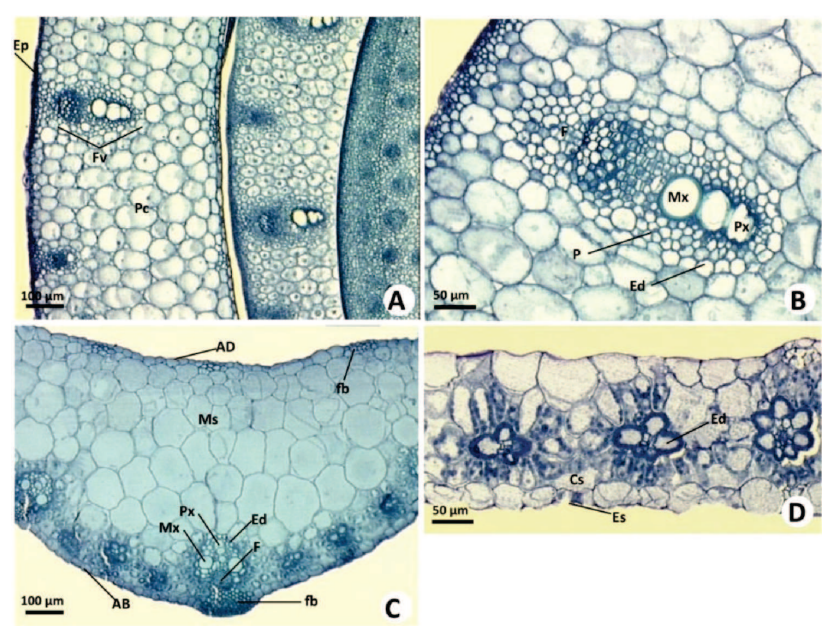

Figure 6. Transversal section of a leaf of corn grown in a nutrient solution containing $75 \mu \mathrm{mol} \mathrm{L}-1 \mathrm{Al}$. a) Sheaths of the stem median region. b) Detail of the external sheath vascular bundle. c) Limbo median region with the mibrid. d) Detail of the vascular bundles and stomata. AB, abaxial face epidermis; AD, adaxial face epidermis; Cs, substomatal chamber; Ed, endodermis; Ep, epidermis; Es, stomata; F, phloem; fb, fiber; Fv, vascular bundle; Ms, mesophyll; Mx, metaxylem; $\mathbf{P}$, pericycle; Pc, cortical parenchyma; and $\mathbf{P x}$, protoxylem. forming the sclerenchyma tissue, providing plant support and covering. The presence of this tissue occurred only in the region near the vascular bundle (Figure 6a). The mesophyll was composed of turgid cells with more intercellular spaces, and the vascular bundle contained the endodermis and the internal pericycle. The protoxylem and metaxylem developed a secondary wall (Figure 6b).

The characteristics of the leaf limbo of these same plants (grown in $75 \mu \mathrm{mol} \mathrm{L}-1 \mathrm{Al}$ ) were the same as those of the control plants, except for the reduced development of the vascular bundles (Figure 6c,d).

The leaf sheath of the plants grown in $300 \mu \mathrm{mol} \mathrm{L}^{-1}$ $\mathrm{Al}$ (Figure 7a) had a uniseriate epidermis coated with a thin cuticle layer, and the epidermis and cortex cells were less developed (Figure $7 \mathrm{~b}$ ). In the vascular bundle, the metaxylem and protoxylem had no secondary walls, and their diameter was much smaller than of the control plants (Figure 7c).

In the leaf limbo of plants grown in nutrient solution containing $300 \mu \mathrm{mol} \mathrm{L}-1 \mathrm{Al}$, the tissue structure was organized but contained fewer and smaller cells due to the lower number of cell layers in the mesophyll (Figure 7d). No secondary walls of the metaxylem and protoxylem were detected in the midrib and the endodermis was not easily identifiable.

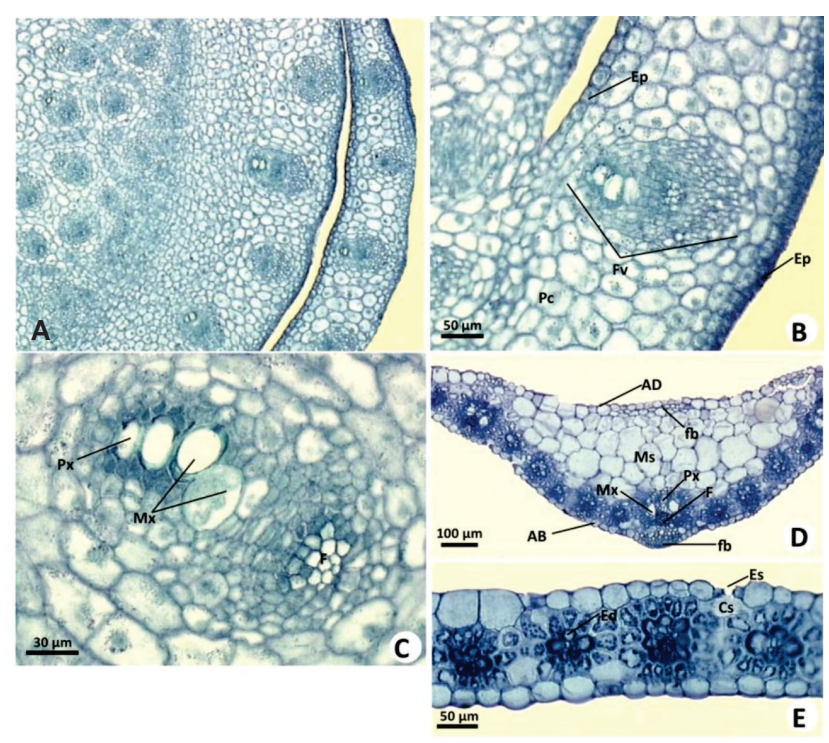

Figure 7. Transversal section of a leaf of corn grown in nutrient solution containing $300 \mu \mathrm{mol} \mathrm{L}-1 \mathrm{Al}$. a, b) Sheaths of the stem median region. c) Detail of the external sheath vascular bundle. d) Limbo median region with the midrib. e) Detail of the vascular bundles and stomata. $A B$, abaxial face epidermis; $\mathrm{AD}$, adaxial face epidermis; Cs, substomatal chamber; Ed, endodermis; Ep, epidermis; Es, stomata; F, phloem; fb, fiber; Fv, vascular bundle; Ms, mesophyll; Mx, metaxylem; $P$, pericycle; Pc, cortical parenchyma; and $\mathbf{P x}$, protoxylem. 
Moreover, the amount of cells in the sclerenchyma tissue was lower than at lower $\mathrm{Al}$ concentrations (Figure $7 \mathrm{~d}$ ). In plants grown at $300 \mu \mathrm{mol} \mathrm{L}^{-1} \mathrm{Al}$, the (abaxial and adaxial) epidermis had similar sized cells, although in the control the adaxial epidermis developed cells with larger sizes than the abaxial epidermis (Figure 7e).

\section{CONCLUSIONS}

1. Under the conditions used in this study, $\mathrm{Al}$ negatively influenced the corn plants by affecting early growth and dry weight production, especially at the higher $\mathrm{Al}$ concentrations, in the experimental period.

2. The plants showed a greater morphologic difference when compared to the anatomical features of the vegetative organs at higher $\mathrm{Al}$ concentrations as a result of the phytotoxic action in the growth period.

3. The following anatomical features were slightly changed at $75 \mu \mathrm{mol} \mathrm{L}{ }^{-1} \mathrm{Al}$ : larger metaxylem diameter with oval shape and reduced perimedular region. The plants grown at $300 \mu \mathrm{mol} \mathrm{L} \mathrm{L}^{-1} \mathrm{Al}$ developed a cortical parenchyma with larger cells and a cell wall with a wavy aspect, and the endodermis with "U" thickening was not evident in the endodermis. Moreover, it was difficult to distinguish the phloem and pericycle cells in the central cylinder of plants grown at $300 \mu \mathrm{mol} \mathrm{L}^{-1} \mathrm{Al}$. Furthermore, the metaxylem and protoxylem did not reach maturation at the highest $\mathrm{Al}$ concentration, so they lacked a definite shape, had a reduced diameter and a poorly developed perimedular region.

\section{LITERATURE CITED}

AZEVEDO, A.A. \& OLIVA, M.A. Effect of aluminum on productivity and mineral elements in soybean. Pesq. Agropec. Bras., 24:1537-1546, 1989.

BARCELÓ, J.; POSCHENRIEDER, C.; VÁZQUEZ, M.D. \& GUNZÉ, B. Aluminum phytotixicity. Fert. Res., 43:217$223,1996$.

BATISTA, M.A.; PINTRO, J.C.; COSTA, A.C.S.; TORMENA, C.A.; BONATO, C.M. \& BATISTA, M.F. Mineral composition and dry mass production of the corn plants in response to phosphorus sources and aluminum concentration. Braz. Arch. Biol. Technol., 52:541-548, 2009.

BENNET, R.J. \& BREEN, C.M. The recovery of the roots of Zea mays L. from various aluminium treatments: Towards elucidating the regulatory processes that underlie root growth control. Environ. Exper. Bot., 31:153-163, 1991.

BENNET, R.J.; BREEN, C.M. \& FEY, M.V. The effects of aluminium on root cap function and root development in Zea mays L. Environ. Exper. Bot., 27:99-104, 1987.
BEUTLER, A.N.; FERNANDES, L.A. \& FAQUIN, V. Aluminum effect on the growth of two forest species. R. Bras. Ci. Solo, 25:923-928, 2001.

BLAIR, L.M. \& TAYLOR, G.J. Maintaining exponential grown, solution conductivity, and solution $\mathrm{pH}$ in low-ionic-strength solution culture using a computer-controlled nutrient delivery system. J. Exper. Bot., 55:1557-1567, 2004.

BLAMEY, F.P.C.; EDMEADES, D.C. \& WHEELER, D.M. Role of cation-exchange capacity in differential aluminum tolerance of Lotus species. J. Plant Nutr., 13:729-744, 1990.

BLANCAFLOR, E.B.; JONES, D.L. \& GILORY, S. Alterations in the cytoskeleton accompany aluminum-induced growth inhibition and morphological changes in primary roots of maize. Plant Physiol., 118:159-172, 1998.

BRITO, C.J.F.A.; RODELLA, R.A.; DESCHAMPS, F.C. \& ALQUINI, Y. Structured organization in leaf blade and sheath of elephant grass cultivars (Pennisetum purpureum Schum. - POACEAE). Arq. Biol. Tecnol., 40:661-67, 1997

BUDÍKOVÁ, S.; CIAMPOROVÁ, M.; OVECKA, M. \& POLONYI, J. Structural characterization of maize root tip cells under aluminium stress. Acta FRN Univ. Comen., 29:47-52, 1997.

CHA, D.H. \& LEE, D.K. Effects of different aluminum levels on growth and root anatomy of Alnus hirsuta Rupr. seedlings. J. Sustain. For., 3:45-63, 1996.

CIAMPOROVÁ, M. Diverse response of root cell structure to aluminium stress. Plant Soil, 226:113-116, 2000.

CLARK, R.B. Effects of aluminum on growth and mineral elements of Al-tolerant and Al-intolerant corn. Plant Soil, 47:653-662, 1997.

DELEERS, M.; SERVAIS, J.P. \& WULFERT, E. Neurotoxic cations induce membrane rigidification and membrane fusion at micromolar concentrations. Biochim. Biophys. Acta, 855:271-276, 1986

DELHAIZE, E. \& RYAN, P.R. Aluminum toxicity and tolerance in plants. Plant Physiol., 107:315-321, 1995.

DELMER, D.P. \& AMOR, Y. Cellulose biosynthesis. Plant Cell, 7:987-1000, 1995.

ECHART, C.L. \& CAVALLI-MOLINA, S. Aluminum phytotoxicity: Effects, tolerance mechanisms and its genetic control. Ci. Rural, 31:531-541, 2001.

ESAU, K. Anatomia vegetal. 2. ed. Barcelona: Ediciones Omega, 1959. 729 p.

FOOD AND AGRICULTURE ORGANIZATION OF THE UNITED NATIONS - FAO. Statistics Division. Maize, rice and wheat: Area harvested, production quantity, yield. 2010. Available: <http://faostat.fao.org/site/567/>. Accessed May 4, 2012.

FARIAS, E.S.T.; PINTRO, J.C.; DA SILVA, M.A.G.; MUNIZ, A.S.; MARCHETTI, M.E.; NOLLA, A. \& NOEMI, P. Aluminum toxicity in corn plants cultivated with low and high ionic strength nutrient solutions. J. Plant Nutr., 34:465-475, 2011. 
FOY, C.D. The physiology of plant adaptation to mineral stress. Iowa State J. Res., 57:355-391, 1983.

GÖRANSSON, A. \& ELDHUSET, T.D. Effects of aluminium on growth and nutrient uptake of small Picea abies and Pinus sylvestris plants. Trees, 5:136-142, 1991.

GUERRITS, P.O. The application of glycol methacrylate in histotechnology: Some fundamental principles. Groningen, Department of Anatomy and Embryology State University, 1991. 80p.

HORST, W.J.; PUSCHEL, A.K. \& SCHOMHL, N. Induction of callose formation is a sensitive marker for genotypic aluminum sensitivity in maize. Plant Soil, 192:23-30, 1997.

HORST, W.J.; SCHOMHL, N.; KOLLMEIER, M.; BALUSCA, F. \& SIVAGURU, M. Does aluminium inhibit root growth of maize through interaction with the cell wall-plasma membrane-cytoskeleton continuum? Plant Soil, 215:163$174,1999$.

IKEDA, H. \& TADANO, T. Ultrastructural changes of the root tip cell in barley induced by a comparatively low concentration of aluminum. Soil Sci. Plant Nutr., 39:109117, 1993.

JENSEN, W.A. Botanical histochemistry: Principles and practice. San Francisco, 1962. 408p.

JONES, D.L. \& KOCHIAN, L.V. Aluminum inhibition of the inositol 1,4,5- triphosphate signal transduction pathway in wheat roots: A role in aluminum toxicity? Plant Cell, 7:1913-1922, 1997.

JOHANSEN, D.A. Plant microtechnique. New York, Mc GrawHill Book, 1940. 523p.

KINRAIDE, T.B. \& PARKER, D.R. Cation amelioration of aluminum toxicity in wheat. Plant Physiol., 83:546-551, 1987.

KOCHIAN, L.V. Cellular mechanisms of aluminum toxicity and resistance in plants. Ann. Rev. Plant Phys., 46:237$260,1995$.

KOCHIAN, L.V. Molecular physiology of mineral nutrient acquisition, transport and utilization. In: BUCHANAN, B.B.; GRUISSEM, W. \& JONES, D.L., eds. Biochemistry and molecular biology of plants. Rockville, American Society of Plants Physiologist, 2000. p.1239-1243.

KOCHIAN, L.V.; HOEKENGA, O.A. \& PIÑEROS, M.A. How do crop plant tolerate acid soil? Mechanisms of aluminum tolerance and phosphorus efficiency. Ann. Rev. Plant Biol., 55:5459-493, 2004.

KRAUS, J.E.; LOURO, R.P.; ESTELITA, M.E.M. \& ARDUIN, M. A célula vegetal. In: APPEZZATO-DA-GLÓRIA, B. \& CARMELLO-GUERREIRO, S.M., eds. Anatomia vegetal. Viçosa, MG, Universidade Federal de Viçosa, 2003. p.31-86.

LIMA, M.L. \& COPELAND, L. Changes in the ultrastructure of the root tip of wheat following exposure to aluminium. J. Plant Physiol., 21:85-94, 1994.
MATSUMOTO, H. Cell biology of aluminum toxicity and tolerance in higher plants. Int. Rev. Cytol.. 200:1-46, 2000.

MATSUMOTO, H. \& MOTODA, H. Aluminum toxicity recovery processes in rootapices. Possible association with oxidative stress. Plant Sci., 185/186:1-8, 2012.

MENEZES, N.L.; SILVA, D.C. \& MELO DE PINNA, G.F.A. Folha. In: APPEZZATO-DA-GLÓRIA, B. \& CARMELLOGUERREIRO, S.M., eds. Anatomia vegetal. Viçosa, MG, Universidade Federal de Viçosa, 2003. p.303-325.

O'BRIEN, T.P.; FEDER, N.E. \& McCULLY, M.E. Polychromatic staining of plant cell wall by toluidine blue. Protoplasma, 59:368-37, 1964.

OUZOUNIDOU, G.; CIAMPOROVÁ, M.; MOUSTAKAS, M. \& KARATAGLIS, S. Responses of maize (Zea mays L.) plants to copper stress I. Growth, mineral content and ultrastucture of roots. Environ. Exper. Bot., 35:167-176, 1995.

PAPERNIK, L.A. \& KOCHIAN, L.V. Possible involvement of $\mathrm{Al}$-induced electrical signals in $\mathrm{Al}$ tolerance in wheat. Plant Physiol., 115:657-667, 1997.

PAVAN, M.A. \& BINGHAN, F.T. Toxicity of aluminum to coffee seedlings grown in nutrient solution. Soil Sci. Soc. Am. J., 46:993-997, 1982.

PINTRO, J.; BARLOY, J. \& FALLAVIER, P. Aluminum toxicity in corn plants cultivated in a low ionic strength nutrient solution. I. Discrimination of two corn cultivars. Braz. J. Plant Physiol., 7:121-128, 1995.

PINTRO, J.C.; BARLOY, J. \& FALLAVIER, P. Aluminum effects on the grown and mineral composition of corn plants cultivated in nutrient solution at low aluminum activity. J. Plant Nutr., 19:729-74, 1996.

RHEINHEIMER, D.S.; PETRY, C.; KAMINSKI, J. \& BARTZ, H.R. Aluminum stress in tobacco plants: I. Effects on phosphorus and calcium uptake, root system and dry matter production. R. Bras. Ci. Solo, 18:63-68, 1994.

RYAN, P.R.; DITOMASO, J.M. \& KOCHIAN, L.V. Aluminum toxicity in roots: an investigation of special sensitivity and role of the root cap. J. Exper. Bot., 44:437-446, 1993.

SAS Institute Inc. SAS/STAT. User's guide, version 8.0. Cary, 2000.

SASS, J.E. Botanical microtechnique. Ames, Iowa State College Press, 1951. 228p.

SCATENA, V.L. \& SCREMIN-DIAS, E. Parênquima, colênquima e esclerênquima. In: APPEZATO-DAGLÓRIA, B.; CARMELLO-GUERREIRO, S.M., eds. Anatomia vegetal. Viçosa, MG, Universidade Federal de Viçosa, 2003. p.109-127.

SCHMOHL, N. \& HORST, W. Cell wall pectin content modulates aluminium sensitivity of Milho L. cells grown in suspension culture. Plant Cell Environ., 23:735-742, 2000.

SEAGULL, R.W. The plant cytoskeleton. Crit. Rev. Plant Sci., 8:131-167, 1989 
SIVAGURU, M.; YAMAMOTO, Y. \& MATSUMOTO, H. Differential impacts of aluminum on microtubules depends on the growth phase in suspension cultured tobacco cells. Physiol. Plant, 107:110-119, 1999.

SIVAGURU, M.; FUJIWARA, T.; SAMAJ, J.; BALUSKA, F.; YANG, Z.; OSAWA, H.; MAEDA, T.; MORI, T.; VOLKMANN, D. \& MATSUMOTO, H. Aluminuminduced 13 -D-glucan inhibits cell-to-cell trafficking of molecules through plasmodesmata. A new mechanism of aluminum toxicity in plants. Plant Physiol., 124:9911006,2000 .
TAYLOR, G.J.; BLAMEY, F.P.C. \& EDWARDS, D.G. Antagonist and synergistic interactions between aluminium and manganese on growth of Vignia unguiculata at low ionic strength. Physiol. Plant., 104:183-194, 1998.

VELOSO, C.A.C.; MALAVOLTA, E.; MURAOKA, T. \& CARVALHO, E.J.M. Aluminum and calcium absorption by black pepper seedlings. Sci. Agr., 57:141-145, 2000.

von UEXCKULL, H.R. \& MUTERT, E. Global extent, development and economic impact of acid soils. Plant Soil, 149:255-261, 1995. 